Doi: 10.32481/djph.2021.09.020

\title{
Helping Mothers Have Healthy Babies
}

Sarah Wells

University of Delaware; Intern, Delaware Academy of Medicine / Delaware Public Health Association

\section{Introduction}

Infant mortality is the death of a child before the age of one year. The infant mortality rate (IMR) in a population is a defining characteristic of the health of that community. Public health officials can use IMR to determine the health of a community and create strategies to improve health. In 2020, Delaware saw about a 7.0 infant mortality rate. ${ }^{1}$ This is higher than the national average of $5.7 .^{2}$ There are a variety of risk factors that contribute to infant mortality, with the most common being preterm birth, low birth weight, and the social determinants of health.

Delaware's IMR is higher than the national average, so I chose to create a program for infant mortality. I want to find out why the infant mortality rate is so high in Delaware, why there are differences in IMR between racial groups, and where, geographically, the highest rates of IMR are within the state. This paper will provide the background, theory, and logic model to demonstrate the need for the implementation of the Helping Mothers Have Healthy Babies program.

\section{Background}

Infant mortality is described as the death of a child before the age of one year. Understanding the infant mortality rate (IMR) is key in comprehending the overall health of a society, and looking into infant mortality can give a window into the quality of healthcare provided in a population. It can be seen as an indicator of community health status, poverty, and socioeconomic status levels in the community, and of the healthcare and medical services provided within the community. ${ }^{3}$

\section{Infant Mortality Rate}

The rate of infant mortality is described as number of deaths per every 1,000 live births. The utilization of IMR can be crucial in understanding which areas of the world carry increased rates of infant mortality compared to other locations. Globally, there has been a decrease in infant deaths. In 1990, the rate was 65 deaths per 1,000 live births, and in 2018 it shifted downward to 29 deaths per 1,000 live births. ${ }^{4}$ The World Health Organization (WHO) also reported that in 2018 the region with the highest risk of infant mortality was the WHO African Region, at 52 deaths per 1,000 live births. ${ }^{4}$ This is seven times as high as the WHO European Region at 7 deaths per 1,000 live births. ${ }^{4}$

Though the United States is a developed country, it ranks $33^{\text {rd }}$ out of 36 in infant mortality compared to other Organization for Economic Co-operation and Development (OECD) countries. ${ }^{5}$ The United States' IMR falls around 5.9 deaths per 1,000 live births, compared to the average rate of 3.9 deaths per 1,000 live births of the other OECD countries. ${ }^{5}$ In 2018, the US saw over 21,000 infant deaths, and this continues to be a large burden on the population. The United States rates of infant mortality vary heavily by race, with non-Hispanic Black women bearing the highest rate at 10.8 deaths per 1,000 live births. ${ }^{2}$ Rates vary by state as well, and in 
2019, New Hampshire had the lowest IMR with 3.07 per 1,000, while Louisiana carried the highest IMR at 8.07 deaths per 1,000 live births. ${ }^{2}$

Delaware, the second smallest state in the United States, has an IMR of 7.0 deaths per 1,000 live births. ${ }^{6}$ This is significantly higher than the US national average of 5.9. Along with the rest of the country, women of color in the State of Delaware face higher rates of infant mortality as opposed to their White counterparts. The rate for non-Hispanic Black women in Delaware is 12.6 deaths per 1,000 live births, which is higher than the national average, as opposed to White women, whose rate is only 4.8 deaths per 1,000 live births. ${ }^{7}$ Although the rates of infant mortality have been slowly decreasing nationally, there has been an increase in the African American and White infant mortality disparity ratio from 2.0 in 1980 to 2.4 in $2009 .^{3}$

\section{Infant Mortality}

Infant mortality is the death of a baby within their first year of life. There are several causes and risk factors that contribute to infant mortality. Globally, the top five causes of infant mortality include neonatal encephalopathy, infections (especially blood infections), complications of preterm birth, lower respiratory infections, and diarrheal diseases. These causes of death vary between older and younger infants. In the United States, the most common causes of infant mortality are birth defects, preterm birth and low birth weight, sudden infant death syndrome, pregnancy complications, and accidents.

Along with the factors listed above, there are significant racial disparities for rates of infant mortality- both in Delaware and in the United States. For those who have experienced greater social and economic disadvantage, there is an increased risk for infant mortality in these individuals or communities. The lack of health equity by racial and ethnic status, due to exclusion or discrimination, is known to influence health status. ${ }^{3}$ There are health disparities within both Delaware and the United States due to the racial and ethnic identity of citizens.

\section{Epidemiology}

The State of Delaware is the second smallest state in the United States of America and is home to 990,334 residents. ${ }^{8}$ The state is split between only three counties - New Castle, Kent, and Sussex - and includes a variety of urban and rural landscapes and a diverse racial composition. The state is composed of $68.76 \%$ White residents, followed by $22.18 \%$ Black or African American, 3.87\% Asian, $2.83 \%$ two or more races, $1.92 \%$ other race, $0.39 \%$ Native American, and $0.06 \%$ Native Hawaiian or Pacific Islander. Since over $20 \%$ of its population identifies as Black or African American, the state is placed $8^{\text {th }}$ in the nation for a high proportion of residents within this community. ${ }^{8}$

In 2020, Delaware saw about a 7.0 infant mortality rate. ${ }^{1}$ This rate can be broken down by age of mother and the race/ethnicity of mother.

Figure 1 references the different infant mortality rates by age for women in Delaware compared to the United States. The rate for mothers aged 20-24 in Delaware is at 10.9, which is higher than the national average of 7.1. This age group presented the highest prevalence of infant mortality. Mothers aged 30-34 have the lowest infant mortality rate amongst Delaware mothers at 4.7. ${ }^{1}$

Figure 1. Infant Mortality Rate and Mother's Ages, Delaware, and the United States, 2020 
Doi: $10.32481 /$ djph.2021.09.020

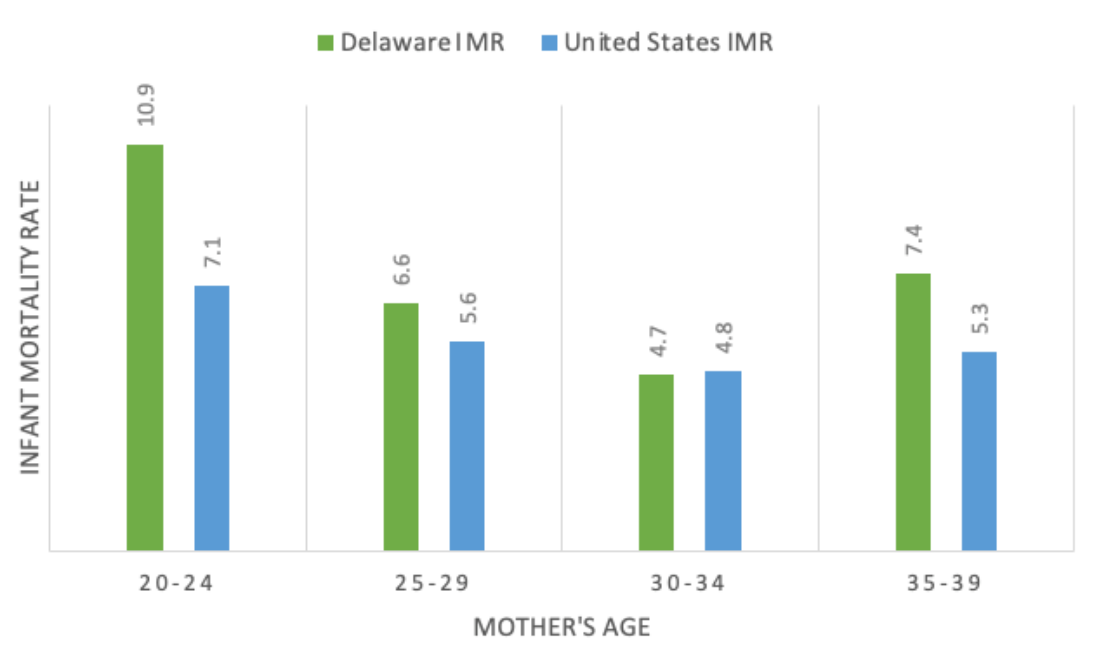

Figure 2 identifies differences in IMR by Race/Ethnicity of women in Delaware, compared to the United States. Black women in Delaware have a 12.6 IMR, and they have the highest IMR in Delaware, while White women have the lowest IMR, which is 4.8. ${ }^{1}$ In 2020, Delaware saw 358 infant deaths in New Castle County, 96 in Sussex County, and 93 in Kent County. ${ }^{9}$

Figure 2. Infant Mortality Rate and Mother's Race, Delaware, and the United States, 2020

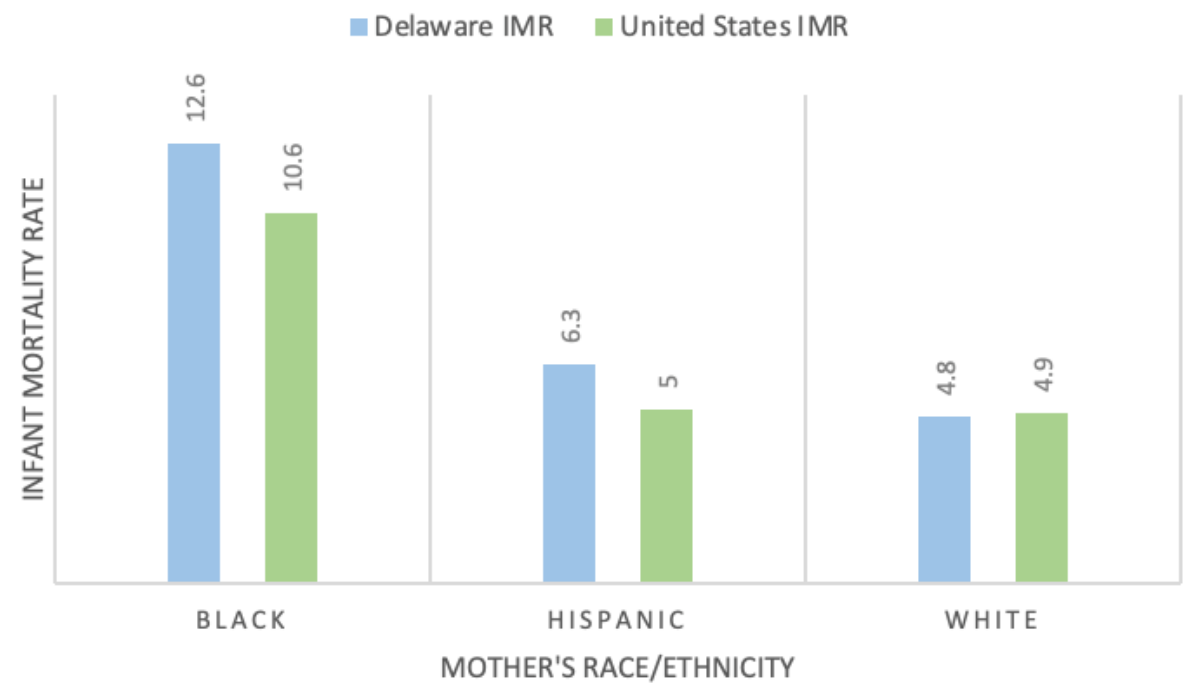

In Delaware, the City of Wilmington (located in New Castle County) has the highest rates of infant mortality. The IMR in Wilmington is 14.5, compared with New Castle County at 6.6. The non-Hispanic Black community has a higher IMR than average in the City of Wilmington at 16.9, and the value for non-Hispanic White women is not recorded. In this same period, it is shown that the IMR in the non-Hispanic Black community in New Castle County is 12.8, versus 4.6 in non-Hispanic White women, which is a $178 \%$ difference. $^{10}$ 


\section{Correlates and Determinants}

\section{Preterm Birth}

Preterm birth is the leading cause of death for infants. In Delaware, the preterm birth rate is $10.7 \%$, so 107.0 babies per 1,000 live births are born before 37 weeks' gestation. ${ }^{7}$ This is higher than the national average of $10.2 \%{ }^{6}$ Delaware has a $1.38 \%$ disparity ratio (divide rate of population $\mathrm{A}$ by the best rate, population $\mathrm{B}$, to find out how much more likely an event is to occur in a population over another) for preterm birth, and in Delaware, non-Hispanic Black women have the highest chance of delivering prematurely at $13.1 \%$, while the White community has only an $8.8 \%$ chance. ${ }^{7}$ The preterm birth rate is disproportionally higher for Black women, and in Delaware, the rate is $51 \%$ higher than the rate among all other women. ${ }^{7}$

\section{Low Birth Weight}

Low birthweight (LBW) is another contributor to infant mortality. Babies born at less than 2,500 grams are considered to be low birth weight. Babies born with low birth weight are more likely to develop breathing problems, bleeding in the brain, patent ductus arteriosus, necrotizing enterocolitis, retinopathy of prematurity, jaundice, and infections. ${ }^{11}$ Delaware's rate of low birth weight is $9.0 \%$, with the national average sitting closer to $8.0 \%$. There are variances of the rate of low-birth-weight babies between different races/ethnicities in Delaware. Asian/Pacific Islander women have the lowest rate at 5.9\%, Hispanic women have a 7.0\% LBW rate, White women in Delaware have a 7.3\% LBW rate, and the highest rate of LBW in Delaware is in Black/African American women at $13.6 \% .^{12}$

\section{Social Determinants}

The social determinants of health (SDOH) refer to the "conditions in which people live, learn, work, and play." "3 The pillars of SDOH include education, healthcare access, economic stability, neighborhoods, and community- these factors help shape the prevalence of infant mortality. These determinants are more than sociodemographic risk factors and play a key role in the health of individuals and their communities.

Demographic risk factors are individual level risk factors; those linked with poor birth outcomes include "race, socioeconomic status, maternal education level, marital status, and health behaviors such as smoking, nutrition, and prenatal care utilization." 14 The social determinants can be explained in individual, interpersonal, organizational, community, and public policy levels. Looking beyond demographics and into social determinants can help close gaps in health disparities by providing targeted health intervention and prevention initiatives.

The interpersonal level focuses on paternal involvement in the pregnancy and intimate partner violence (IPV). IPV during pregnancy is associated with greater risk of preterm birth and low birth weight deliveries, and both are high risk factors for infant mortality. ${ }^{14}$

At the organizational level, availability of and access to medical providers and hospital facilities have proven to have the biggest impact on infant mortality. Assessing a woman's place of residence during the time of birth is important to understand her access to care. Women in rural or impoverished neighborhoods have a lower "proportion of medical specialists, such as obstetricians and neonatologists, relative to the number of births." 14 Having less access to these specialists can increase infant mortality. The level of hospital facility is also a risk for infant 
mortality: Neonatal Intensive Care Units (NICUs) with high-level and high-volume (level III NICU's) have proven to have lower levels of in-hospital infant deaths. ${ }^{14}$

The community level social determinants of health focus on neighborhoods, concentrated poverty, and racial segregation as risks for infant mortality. There are geographical factors that contribute to infant mortality, and there are some areas that have more protective infrastructures than others, which can help reduce that risk. Those protective factors can also be part of the organizational level of SDOH, such as access to high level treatment centers and an abundance of medical specialists. There is also a correlation between neighborhood/concentrated poverty and higher rates of infant mortality. ${ }^{14}$

The African American community faces the poorest birth outcomes out of all the racial/ethnic groups in the United States. This community sees the highest rate of infant mortality, LBW, and preterm birth, and there is a correlation between racial segregation and infant mortality. They are the "most segregated group in the United States, and they are over-represented in high-poverty neighborhoods." 14 Since there is an overrepresentation of the African American community in impoverished neighborhoods, there can be worse birth outcomes amongst this group.

At the policy level, there is a perpetual trend of reinforced inequality in education, housing the economy, and criminal justice that creates an environment of discrimination against minorities. ${ }^{15}$ Pabayo, et al. conducted an ecological study to find whether structural racism increases individual odds for infant mortality among White and Black infants in the US. They used 2010 US Cohort Linked Birth and Infant Death Data Files and looked at the following indicators of structural racism- electoral, employment, and justice system. The team then compared the proportions of Blacks to Whites in these indicators and used multilevel logistic regression to assess the relationship between structural racism indicators and infant mortality. His study found that racial disparities in maternal education and incarceration were found to be a risk factor for infant mortality. The study also observed a relationship between income and increased odds for preterm births. $^{15}$

\section{Babies Born Healthy}

Infant mortality is both a concern for the United States and for Delaware. Preterm birth, low birth weight, and other social determinants such as race, geographical location, poverty, education levels, and employment status contribute to the high rates of infant mortality. Working on narrowing the racial disparity ratio is crucial to lowering IMR.

The Babies Born Healthy Program in Montgomery County, Maryland, helps at-risk pregnant women connect with programs and resources to help them stay healthy during pregnancy. ${ }^{16}$ This may include prenatal education, depression screening, substance abuse help, domestic violence help, and environmental safety issues. They provide education on preterm labor prevention, smoking, family planning, and more. The target population for BBH is pregnant African American women in Montgomery County, Maryland, since they are at the highest risk for both maternal and infant mortality. This program is trying to reduce health disparities and increase positive outcomes in this community. They provide services, like a safe sleeping environment, diapers, transportation to appointments, and more, which reduces many barriers to healthy pregnancies and healthy lives once the baby is delivered. This program is something that can be modeled in the State of Delaware with the specified at-risk population. Providing resources and services for women in the non-Hispanic Black community can help improve birth outcomes. 
The creation of a program in the State of Delaware should focus on providing care to a high-risk population in a high-risk area. This program can include care in the form of providing materials to mothers in need, providing transportation to prenatal care visits, insuring mothers have access to prenatal care, and proper education for new mothers on care pre/post-partum. In Delaware, the highest risk population is non-Hispanic Black women in the City of Wilmington, (19801-19809).

\section{The Health Belief Model}

The Health Belief Model (HBM) was introduced in the 1950s after being developed by G.M. Hochbaum and other social psychologists. At the time, Hochbaum was working for the U.S. Public Health Service and developed this theory to explain why people did not participate in public health programs across the U.S. ${ }^{17}$ From the original theory, published in 1958, it has been expanded by Leventhal, Rosenstock, and Becker ${ }^{18}$

The HBM is a combined approach that looks at both stimulus-response theory and cognitive theory. The HBM claims that action can be explained by affecting the person's valuation of the action and their perception of the likelihood that this action will produce the desired results. This approach investigates how a person's perceptions influence behaviors. The HBM associates health behaviors with demographic factors- race, income level, education, etc.- and elevates these factors' importance when referencing personal perceptions of health behaviors.

The HBM is made of six constructs: perceived susceptibility, perceived severity, perceived benefits, and perceived barriers were in the original theory; cue to action, and self-efficacy were added as the model evolved. Perceived susceptibility is described as a person's own perception of their risk of obtaining an illness or disease. Perceived severity refers to a person's feelings on the seriousness of contracting a disease or illness. Perceived benefits are a person's perception of the efficacy of different treatments available to reduce the risk of illness or disease. Perceived barriers are a person's perceived obstacles to performing this health behavior or taking a recommended action. Cue to action is a stimulus to trigger a decision to accept a recommended health action. Self-efficacy refers to the level of confidence someone has in their own ability to perform a health behavior.

The HBM works to increase awareness of a health risk in people's lives. For the purposes of Helping Mothers Have Healthy Babies (HMHHB), the HBM will assist in explaining the risk factors for higher IMR by utilizing the constructs of perceived susceptibility and perceived severity. Helping Mothers Have Healthy Babies is focused on reaching non-Hispanic Black women in the City of Wilmington, since this is the highest risk population in Delaware. To relay both perceived susceptibility and perceived severity, the program will pull from both national and state epidemiological data to educate this group on their risk for IMR. Utilizing the construct of perceived benefits, Helping Mothers Have Healthy Babies will help explain the benefits of seeking proper care for pregnancy, and barriers to treatment can be addressed. Many of the barriers that women in the non-Hispanic Black community face involve the SDOH. The information presented will need to reflect the racial inequity that this population faces, and how the program aims to help bridge that gap. This educational presentation will help women understand the importance of receiving proper care during pregnancy, while also acknowledging the barriers faced by this population in this geographical location. Helping Mothers Have Healthy Babies will call people to act; to seek out change in their current health behaviors after learning the risks and benefits. Finally, Helping Mothers Have Healthy Babies will increase 
women's self-efficacy in relation to their pregnancies and promote confidence in healthy pregnancies for this cohort.

\section{Helping Mothers Have Healthy Babies}

Helping Mothers Have Healthy Babies includes definition and structure of the program, identification and management of stakeholders, website creation, education, and a communication plan. The program aims to help educate non-Hispanic Black women of reproductive age in the City of Wilmington (Zip Codes 19802, 19802, 19803, 19804, 19805, 19806,19807 , and 19809) ${ }^{19}$ on the high risk of infant mortality that is faced by this community. Helping Mothers Have Healthy Babies will produce present a webinar and create a website with access to the live webinar and a recording, along with access to information for doctor's offices, transportation information, and connection to supplies for mothers and newborn babies.

The first section of the Helping Mothers Have Healthy Babies logic model is dedicated to outlining the program (Appendix A). The first objective is to outline the webinar, website, and survey materials, and create a timeline for their implementation. The timeline will be shared with collaborators. The next objective is to define the program goals and create a mission statement to share with interested collaborators. This objective is important for creating vision for the rest of the program. The collaborators will have a chance to participate in the formation of the mission statement and goals.

The next objective in the program is identification and engagement. Helping Mothers Have Healthy Babies will reach out to interested collaborators, including the March of Dimes, the Delaware Healthy Mother and Infant Consortium, and the Delaware Division of Public Health. Finding interested collaborators is essential for the creation of the webinar. These collaborators will be able to provide insight into what information needs to be presented, and potentially present information on the webinar. Once a group of interested collaborators is established, it will be turned into a formal list of stakeholders, and the collaborators will be updated periodically on the progress of the program.

The next objective is the creation of the website. The website is a key piece of Helping Mothers Have Healthy Babies. The site will include access to the webinar- both when it is streamed live and a recording- as well as access to information about connections to clinics/doctor's offices for women for pre-and post-natal care, access to transportation information to get to and from these appointments, and a page for women to find resources for supplies needed during and after pregnancy for both mother and baby. The website will have a launch date of July 2021.

After the creation of the site, the formulation of the webinar and surveys can begin. The first objective is to reach out to the interested collaborators about content for the webinar. The webinar is scheduled for August, so the goal is to have $100 \%$ of the webinar planned and scheduled with speakers by July. The creation of a survey for the attendees of their knowledge before and after the webinar is an important metric to see if the information provided in the webinar is helpful. The data from the surveys will provide insight for the effectiveness of the webinar and can help shape future initiatives.

The final piece of Helping Mothers Have Healthy Babies is the communication plan. These objectives are essential to the program, since this is how the program will reach the target audience. The main goals of the communication plan are to advertise using emails or brochures in different doctor's offices, clinics, hospitals, and emergency rooms in the Wilmington area. 
There will also be a social media initiative for the program as well. Throughout the time of communication initiatives, a list of interested attendees will be formulated from the time they register for the event. This list will be utilized to send updates about the website, webinar, and future events.

\section{Discussion}

\section{Social Determinants of Health}

Infant Mortality relates to the SDOH, since the SDOH are where people play, work, live, and learn. Many of the challenges that non-Hispanic Black women face in infant mortality are attributed to the SDOH. These factors are more than just the sociodemographic risk factors, and they play a vital role in the health of these women and babies. The prevalence of infant mortality is shaped by access to education and healthcare, economic stability, the neighborhoods women live in, and the community that surrounds them. Multiple factors in the SDOH can work together to create barriers for women seeking care. Looking at a woman's place of residence at the time of pregnancy can be an important factor in assessing access to care. Women in neighborhoods that are rural, or face impoverishment, have a smaller chance of finding the proper medical specialists required for pregnancy. On top of that, some women do not have access to healthcare or transportation to get to appointments. For those who do not have healthcare, the emergency department may be a primary source of care.

It is known that the African American community faces the poorest birth outcomes of all racial/ethnic groups in the United States. In 2017, the IMR in African American women was 2.3 times as high as non-Hispanic Whites. ${ }^{20}$ The IMR in 2017 was 11.0 for non-Hispanic Black women, versus 4.7 in non-Hispanic White, and 5.8 in all races. ${ }^{20}$ This community faces a disproportionate amount of people living in poverty, as compared to other racial groups. In Delaware, about $7.3 \%$ of the White community lives in poverty, while $17.3 \%$ of the Black community does. The poorest birth outcomes- highest rate of infant mortality, LBW, and preterm birth- are not accidental or isolated incidents. They are related to the racial segregation of the Black community and the high percentages of those living in poverty. ${ }^{21}$

The SDOH include ways to take effective actions at the individual interpersonal, organizational, community, and public policy levels. The Helping Mothers Have Healthy Babies program will work in multiple levels; at an organizational level, the program provides access to care, transportation, and baby supplies; on an individual level, it provides education and encouragement for how to reduce the risk of infant mortality for women and their babies.

These determinants play a key role in the health of both mothers and babies. Understanding the impacts the SDOH have on the health of individuals and the health of communities plays a vital role in implementing initiatives that create change.

\section{Epidemiology}

Epidemiology looks to find the causes of health outcomes and diseases in populations. ${ }^{22}$ Health is viewed at a community level, and it looks at the distribution of health-related events in different populations. Epidemiological data is crucial to understanding the cause of a healthrelated problem, which, in this case, is infant mortality. This data helps assess where the problem could be stemming from and allows for a plan to control the problem. 


\section{Health Inequity/Equity}

Health inequities, as described by the World Health Organization, are "differences in health status or in the distribution of health resources between different population groups, arising from the social conditions in which people are born, grow, live, work and age." 23 These barriers in distribution of health resources can be attributed to the differences in social and economic policies between different groups. These policies can create barriers for some groups to seek certain treatment over others.

Health inequity in infant mortality stems from institutional racism, class oppression, and gender discrimination and exploitation. ${ }^{24}$ Health inequity can then trickle down into power and wealth imbalance and create disparities in education, housing, and healthcare for Black women.

Utilizing the social determinants of health to address health inequity can start to tackle problems created by institutional racism, class oppression, and gender discrimination and exploitation. ${ }^{24}$ Addressing transportation, quality of education, availability of food, job security, safe affordable housing, and a living wage can start to create an environment that allows for Black women to deliver healthy babies in a healthy environment. ${ }^{24}$

\section{Other Tasks}

During this internship with the Academy of Medicine/ Delaware Public Health Association, I had a chance to hand in a literature review, annotated bibliography, theory paper, logic model, and logic model comprehension paper. The deliverables created and submitted all fell under the topic of infant mortality and contributed to the Helping Mothers Have Healthy Babies program. Though I have had previous experience with the creation of these documents, I have enjoyed the experience of creating them to use for the program. Doing the research and program creation from start to finish was a gratifying experience, and one that will help me in the future. In the beginning, it was a bit daunting to do research and find a topic that I was passionate about, but once I chose infant mortality, I was able to dive into the deliverables.

My favorite part of this process was the creation of the literature review. I loved spending time finding out everything I could about the topic of infant mortality- the epidemiological data, the causes, disparities, and social determinants. I enjoyed bringing all this information together into one paper that I could reference and utilize as my background for the creation of the Helping Mothers Have Healthy Babies program.

\section{Webpage Design}

As a final portion of my internship with the Academy/DPHA, I created a webpage for the Helping Mothers Have Healthy Babies program. This webpage is in the design of the program in the "website creation" section of the logic model. Though the webpage created does not fully reflect its intended design, it still provides information on the background of the program. This webpage includes a background, causes, and program plan section. All the information on the site came from the research done in this final paper- with the addition of more visual aids (graphs) to help keep the reader engaged. This was my first experience with making a webpage, and I enjoyed the experience. The hardest part was determining which information would be valuable to the site, and which information needed to be cut. I enjoyed creating a deliverable for others to see, and creating this site added to my internship experience. 


\section{Conclusion}

My time interning for the Delaware Public Health Association and Delaware Academy of Medicine was extremely valuable. The experience of finding a topic to create a program for that could be implemented in Delaware was a task I took seriously and one that excited me. I found the experience to be challenging in some ways- mostly lack of previous experience and fatigue from online learning. I also found the experience to be encouraging. I am starting my master's degree (MPH) from the University of Delaware next year, and I will be working as a research assistant. This internship allowed me to work in an environment that will set me up well for graduate school in the fall.

I enjoyed creating a program from start to finish on my own, and I spent a lot of time learning about other programs created for infant mortality that helped shape my program. I was able to learn from others' successes or failures and try to make a program that would really help my target group- non-Hispanic Black women of reproductive age in the City of Wilmington.

\section{References}

1. America's Health Rankings. (2020). Explore Infant Mortality in the United States $\mid 2020$... Infant Mortality. https://www.americashealthrankings.org/explore/health-of-women-andchildren/measure/IMR MCH/state/ALL

2. Centers for Disease Control and Prevention. (2020, September 10). Infant Mortality. Centers for Disease Control and Prevention.

https://www.cdc.gov/reproductivehealth/maternalinfanthealth/infantmortality.htm

3. State Infant Mortality Toolkit. (2009). Why Focus on Infant Mortality. http://www.amchp.org/programsandtopics/dataassessment/InfantMortalityToolkit/Documents/Why\%20Focus\%20on\%20IM.pdf

4. World Health Organization. (2018). Infant mortality. World Health Organization. https://www.who.int/data/gho/data/themes/topics/indicator-groups/indicator-groupdetails/GHO/infant-mortality

5. America's Health Rankings. (2018). Findings International Comparison | 2018 Annual Report $\mid$ AHR. America's Health Rankings.

https://www.americashealthrankings.org/learn/reports/2018-annual-report/findingsinternational-comparison

6. 2020 March of Dimes Report Card United States. (2020). https://www.marchofdimes.org/materials/US_REPORTCARD_FINAL_2020.pdf

7. March of Dimes. (2020). 2020 March of Dimes Report Card Delaware. 2020 March of Dimes Report Card. https://www.marchofdimes.org/peristats/tools/reportcard.aspx

8. World Population Review. (2021). Delaware Population 2021. https://worldpopulationreview.com/states/delaware-population

9. County Health Rankings and Roadmaps. (2020). County Health Rankings \& Roadmaps. County Health Rankings \& Roadmaps- Infant Mortality. https://www.countyhealthrankings.org/app/delaware/2020/measure/outcomes/129/data?sort $=\mathrm{desc}-0$ 
10. Delaware Health and Social Services. (2018). 2018 Annual Report - Delaware Health and Social Services - State of Delaware. https://dhss.delaware.gov/dhss/dph/hp/2018.html

11. March of Dimes. (2018, March). Low birthweight. March of Dimes Low Birthweight. https://www.marchofdimes.org/complications/low-birthweight.aspx

12. America's Health Rankings. (2020). Health of Women and Children-Low Birthweight. America's Health Rankings, Health of Women and Children- Low Birthweight.

13. Centers for Disease Control and Prevention. (2021, March 9). Social Determinants of Health. Centers for Disease Control and Prevention. https://www.cdc.gov/socialdeterminants/index.htm

14. Reno, R., \& Hyder, A. (2018). The evidence base for social determinants of health as risk factors for infant mortality. Journal of Health Care for the Poor and Underserved, 29(4), 1188-1208. PubMed https://doi.org/10.1353/hpu.2018.0091

15. Pabayo, R., Ehntholt, A., Davis, K., Liu, S. Y., Muennig, P., \& Cook, D. M. (2019, December). Structural racism and odds for infant mortality among infants born in the United States 2010. Journal of Racial and Ethnic Health Disparities, 6(6), 1095-1106. PubMed https://doi.org/10.1007/s40615-019-00612-w

16. Maryland Department of Health. (2020). Babies Born Healthy. https://phpa.health.maryland.gov/mch/Pages/BBH.aspx

17. Boston University School of Public Health. (2019). Behavioral Change Models. The Health Belief Model. https://sphweb.bumc.bu.edu/otlt/MPHModules/SB/BehavioralChangeTheories/BehavioralChangeTheories2.html

18. Rosenstock, I. M. (1974). Historical origins of the Health Belief Model. Health Education Monographs, 2(4), 328-335. https://doi.org/10.1177/109019817400200403

19. Wilmington, Delaware (DE) Zip Code Map. (2016). Locations, Demographics. Wilmington, Delaware (DE) list of zip codes. https://www.city-data.com/zipmaps/WilmingtonDelaware.html

20. U.S. Department of Health and Human Services. (2019, November 8). Office of Minority Health. Infant Mortality and African Americans - The Office of Minority Health. https://minorityhealth.hhs.gov/omh/browse.aspx?lvl=4\&lvlid=23

21. Poverty Rate by Race/Ethnicity. (2020, Oct 23). Kaiser Family Foundation. https://www.kff.org/other/state-indicator/poverty-rate-by-raceethnicity/

22. Centers for Disease Control and Prevention. (2016, June 17). What is Epidemiology? Centers for Disease Control and Prevention. https://www.cdc.gov/careerpaths/k12teacherroadmap/epidemiology.html

23. World Health Organization. (2018, February 22). Health inequities and their causes. World Health Organization. https://www.who.int/news-room/facts-in-pictures/detail/healthinequities-and-their-causes

24. Crear-Perry, J. (2017). Health Equity to Address Black Infant Mortality. http://www.healthystartepic.org/wpcontent/uploads/2017/08/NBECNYCRegionalHealthyStart17.pdf 


\section{Appendix A}

Logic Model- Helping Mothers Have Healthy Babies

\begin{tabular}{|c|c|c|c|c|c|}
\hline Goal & & $\begin{array}{l}\text { Implementation } \\
\text { Activities/Objectives }\end{array}$ & $\begin{array}{l}\text { Short Term } \\
\text { Deliverables }\end{array}$ & $\begin{array}{l}\text { Mid Term } \\
\text { Outputs }\end{array}$ & $\begin{array}{l}\text { Long Term } \\
\text { Outcomes }\end{array}$ \\
\hline \multirow[t]{2}{*}{$\begin{array}{l}\text { Define \& } \\
\text { Structure }\end{array}$} & 1 & $\begin{array}{l}\text { Create outline for } \\
\text { webinar, website, and } \\
\text { survey materials }\end{array}$ & $\begin{array}{l}\text { 4/2021- Create } \\
\text { timeline of } \\
\text { surveys, webinar, } \\
\text { and website } \\
\text { development }\end{array}$ & $\begin{array}{l}\text { 5/2021- Lock } \\
\text { down timeline to } \\
\text { share with } \\
\text { collaborators }\end{array}$ & \\
\hline & 2 & $\begin{array}{l}\text { Define program } \\
\text { goals/outline \& } \\
\text { mission statement to } \\
\text { provide to interested } \\
\text { collaborators. Allow } \\
\text { for edits from } \\
\text { collaborators. }\end{array}$ & $\begin{array}{l}4 / 2021 \text { - Define } \\
\text { goals, program } \\
\text { outline, \& mission } \\
\text { statement }\end{array}$ & $\begin{array}{l}5 / 2021- \\
\text { Finalize the } \\
\text { goals, program } \\
\text { outline, \& } \\
\text { mission } \\
\text { statement }\end{array}$ & $\begin{array}{l}6 / 2021- \\
\text { content is } \\
\text { edited as } \\
\text { needed }\end{array}$ \\
\hline \multirow[t]{2}{*}{$\begin{array}{l}\text { Identification \& } \\
\text { Engagement }\end{array}$} & 1 & $\begin{array}{l}\text { Reach out to interested } \\
\text { collaborators for } \\
\text { support (March of } \\
\text { Dimes, DHMIC, DPH) }\end{array}$ & $\begin{array}{l}4 / 2021 \text { - Outreach } \\
\text { to gather } \\
\text { interested parties }\end{array}$ & $\begin{array}{l}5 / 2021-\text { Meeting } \\
\text { for all interested } \\
\text { in program }\end{array}$ & $\begin{array}{l}\text { All parties } \\
\text { involved are } \\
\text { brought in } \\
\text { on the } \\
\text { program }\end{array}$ \\
\hline & 2 & $\begin{array}{l}\text { Develop a list of } \\
\text { interested } \\
\text { collaborators }\end{array}$ & $\begin{array}{l}4 / 2021-\text { Develop } \\
\text { list of those } \\
\text { contacted as a } \\
\text { collaborator for } \\
\text { the webinar }\end{array}$ & $\begin{array}{l}\text { Create finalized } \\
\text { list of } \\
\text { collaborators for } \\
\text { the program }\end{array}$ & $\begin{array}{l}\text { List of } \\
\text { collaborators } \\
\text { updated as } \\
\text { needed }\end{array}$ \\
\hline \multirow[t]{3}{*}{$\begin{array}{l}\text { Website } \\
\text { Creation }\end{array}$} & 1 & $\begin{array}{l}\text { Create a website with } \\
\text { resources and } \\
\text { information for the } \\
\text { target audience about } \\
\text { IMR in Delaware. } \\
\text { Identify items that } \\
\text { need to be added to the } \\
\text { website. }\end{array}$ & $\begin{array}{l}\text { Website launch } \\
7 / 2021\end{array}$ & $\begin{array}{l}6 / 2021-50 \% \text { of } \\
\text { women in target } \\
\text { population } \\
\text { aware of website } \\
\text { launch and } \\
\text { resources }\end{array}$ & $\begin{array}{l}\text { 7/2021- all } \\
\text { women in } \\
\text { target } \\
\text { population } \\
\text { aware of } \\
\text { website } \\
\text { resources. } \\
\text { Website } \\
\text { launch } \\
\text { in } 7 / 2021 \text {. }\end{array}$ \\
\hline & 2 & $\begin{array}{l}\text { Create page on site for } \\
\text { Webinar to be } \\
\text { accessed live. Once } \\
\text { the webinar has } \\
\text { passed, upload } \\
\text { recording. }\end{array}$ & $\begin{array}{l}5 / 2021 \text { - create a } \\
\text { place on the site } \\
\text { for discussing } \\
\text { upcoming } \\
\text { webinar. }\end{array}$ & $\begin{array}{l}\text { 7/2021- webinar } \\
\text { date in } 7 / 2021\end{array}$ & $\begin{array}{l}\text { Upon } \\
\text { webinar } \\
\text { completion, } \\
\text { it is } \\
\text { uploaded to } \\
\text { the site. }\end{array}$ \\
\hline & 3 & $\begin{array}{l}\text { Page created on site } \\
\text { for access to } \\
\text { clinics/doctor's offices } \\
\text { for women for } \\
\text { pre/post-natal care }\end{array}$ & $\begin{array}{l}5 / 2021 \text { - create } \\
\text { page on site for } \\
\text { where women can } \\
\text { find places for } \\
\text { care }\end{array}$ & $\begin{array}{l}\text { Maintenance } \\
\text { and updates in } \\
\text { this section of } \\
\text { the site as } \\
\text { needed }\end{array}$ & \\
\hline
\end{tabular}




\begin{tabular}{|c|c|c|c|c|c|}
\hline & 4 & $\begin{array}{l}\text { Create page on site for } \\
\text { access to } \\
\text { transportation to and } \\
\text { from appointments }\end{array}$ & $\begin{array}{l}5 / 2021 \text { - create } \\
\text { page on site for } \\
\text { women to find } \\
\text { transportation for } \\
\text { their appointments }\end{array}$ & $\begin{array}{l}\text { Maintain this } \\
\text { section of the } \\
\text { site }\end{array}$ & \\
\hline & 5 & $\begin{array}{l}\text { Create page on the site } \\
\text { for access to supplies } \\
\text { for newborn babies } \\
\text { and pregnancy }\end{array}$ & $\begin{array}{l}5 / 2020 \text { - create } \\
\text { section of site for } \\
\text { women to find } \\
\text { free supplies for } \\
\text { their } \\
\text { pregnancies/babies }\end{array}$ & $\begin{array}{l}\text { Maintain this } \\
\text { section of the } \\
\text { site }\end{array}$ & \\
\hline \multirow[t]{3}{*}{ Education } & 1 & $\begin{array}{l}\text { Reach out to interested } \\
\text { collaborators about } \\
\text { webinar creation }\end{array}$ & $\begin{array}{l}5 / 2021 \text { - reach out } \\
\text { to all collaborators } \\
\text { for webinar } \\
\text { content }\end{array}$ & $\begin{array}{l}\text { 6/2021- } \\
\text { collaborators } \\
\text { have responded }\end{array}$ & $\begin{array}{l}\text { Webinar } \\
\text { scheduled } \\
\text { for } 8 / 2021\end{array}$ \\
\hline & 2 & Webinar Creation & $\begin{array}{l}\text { 5/2021- start } \\
\text { working with } \\
\text { collaborators on } \\
\text { webinar content }\end{array}$ & $\begin{array}{l}6 / 2021-50 \% \text { of } \\
\text { webinar is } \\
\text { scheduled }\end{array}$ & $\begin{array}{l}7 / 2021- \\
100 \% \text { of } \\
\text { webinar is } \\
\text { scheduled } \\
\text { with } \\
\text { speakers. }\end{array}$ \\
\hline & 3 & Survey Creation & $\begin{array}{l}6 / 2021-\text { create } \\
\text { pre/post webinar } \\
\text { survey to see what } \\
\text { the audience has } \\
\text { learned }\end{array}$ & $\begin{array}{l}7 / 2021-75 \% \text { of } \\
\text { registered } \\
\text { attendees take } \\
\text { the pre webinar } \\
\text { survey }\end{array}$ & $\begin{array}{l}8 / 2021-75 \% \\
\text { of registered } \\
\text { attendees } \\
\text { take the post } \\
\text { webinar } \\
\text { survey }\end{array}$ \\
\hline \multirow[t]{4}{*}{$\begin{array}{l}\text { Communication } \\
\text { Plan }\end{array}$} & 1 & $\begin{array}{l}\text { Advertise for } \\
\text { website/webinar in } \\
\text { clinics and doctor's } \\
\text { offices in the } \\
\text { Wilmington area } \\
(19801-19809)\end{array}$ & $\begin{array}{l}5 / 2021-\text { Contact } \\
\text { these locations to } \\
\text { talk about the } \\
\text { website/webinar }\end{array}$ & $\begin{array}{l}6 / 2021-\text { Decide } \\
\text { a form of } \\
\text { communication } \\
\text { to patients with } \\
\text { these offices } \\
\text { (brochures, } \\
\text { emails, etc) }\end{array}$ & $\begin{array}{l}\text { Continue to } \\
\text { provide }\end{array}$ \\
\hline & 2 & $\begin{array}{l}\text { Outreach to interested } \\
\text { attendees }\end{array}$ & $\begin{array}{l}5 / 2021-\text { Research } \\
\text { where to reach } \\
\text { those that are } \\
\text { eligible for the } \\
\text { program }\end{array}$ & $\begin{array}{l}6 / 2021 \text { - Provide } \\
\text { information to } \\
\text { clinics/doctor's } \\
\text { offices about } \\
\text { program, so they } \\
\text { can tell their } \\
\text { patients }\end{array}$ & $\begin{array}{l}\text { All women } \\
\text { interested in } \\
\text { the program } \\
\text { are invited to } \\
\text { join }\end{array}$ \\
\hline & 3 & $\begin{array}{l}\text { Outreach to } \\
\text { ER/Hospitals to } \\
\text { distribute information } \\
\text { to eligible women }\end{array}$ & $\begin{array}{l}5 / 2021-\text { Reach out } \\
\text { to hospitals in } \\
\text { target zip codes }\end{array}$ & $\begin{array}{l}6 / 2021-50 \% \\
\text { brochures } \\
\text { distributed to } \\
\text { hospitals }\end{array}$ & $\begin{array}{l}7 / 2021- \\
100 \% \\
\text { brochures } \\
\text { distributed } \\
\end{array}$ \\
\hline & 4 & $\begin{array}{l}\text { Create brochures to } \\
\text { distribute to offices }\end{array}$ & $\begin{array}{l}5 / 2021-\text { create } \\
\text { brochures to be } \\
\text { distributed to } \\
\text { offices about the } \\
\text { webinar/website }\end{array}$ & $\begin{array}{l}6 / 2021-50 \% \text { of } \\
\text { brochures } \\
\text { distributed }\end{array}$ & $\begin{array}{l}7 / 2021- \\
100 \% \\
\text { brochures } \\
\text { distributed; } \\
\text { more }\end{array}$ \\
\hline
\end{tabular}




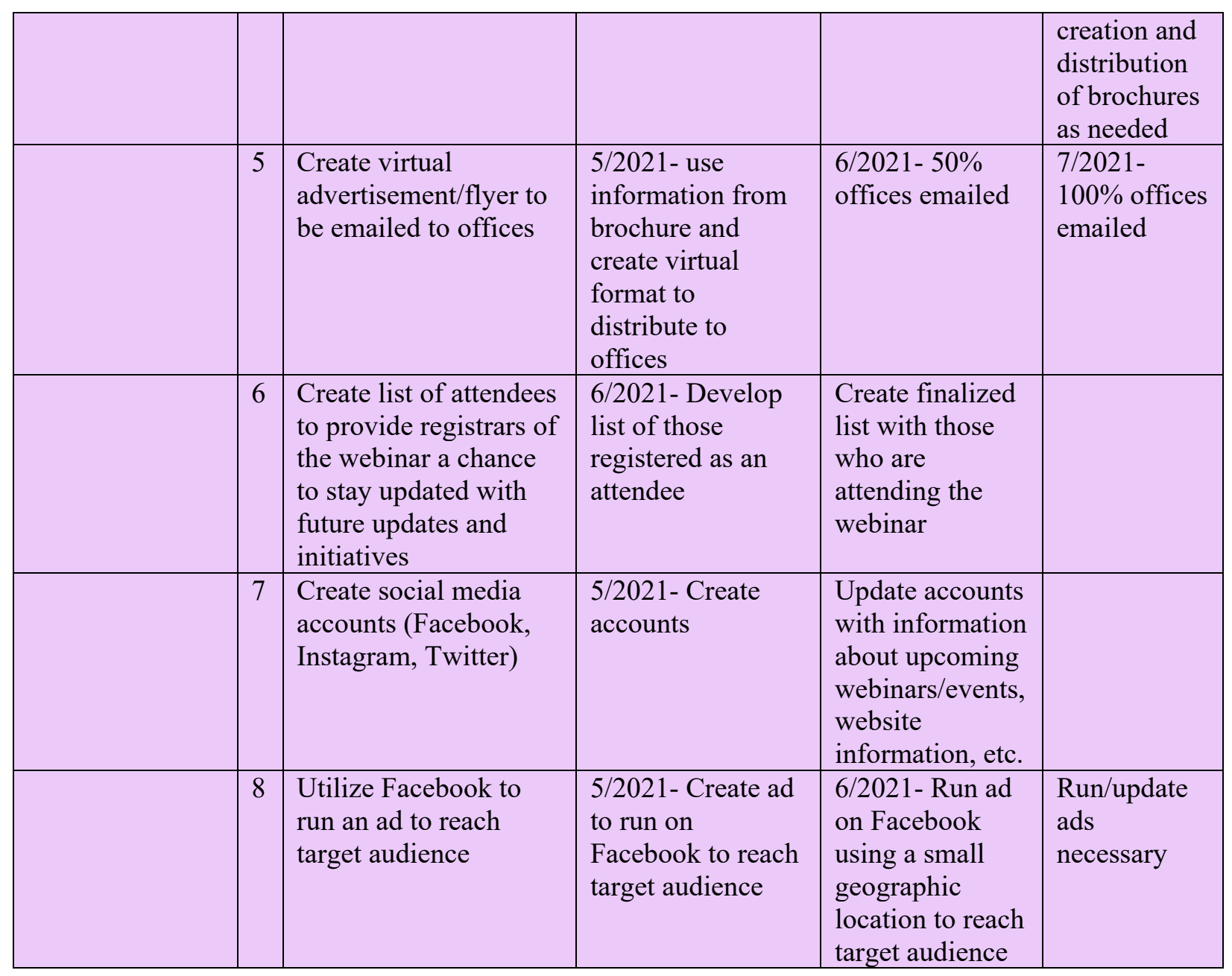

Copyright (c) 2021 Delaware Academy of Medicine / Delaware Public Health Association.

This is an Open Access article distributed under the terms of the Creative Commons Attribution Non-Commercial License (https://creativecommons.org/licenses/by-nc-nd/4.0/) which permits unrestricted non-commercial use, distribution, and reproduction in any medium, provided the original work is properly cited. 